\title{
PERANCANGAN METRIK DAN PENGUKURAN KINERJA RANTAI PASOK DI PT SIERAD PRODUCE, TBK.
}

\author{
Revi Agustian dan Elisa Kusrini \\ Magister Teknik Industri \\ Universitas Islam Indonesia \\ Email : revi_agustian@yahoo.com
}

\begin{abstract}
$\mathrm{T}_{\mathrm{cos}}^{\mathrm{h}}$ The competition maps of the industry will change from one country to be the ASEAN regional in 2015 as the commencement of globalization in the ASEAN Economic Community. Performance of supply chain will become more strategic for domestic companies to increase their competitiveness.

The approach used for designing and measuring of supply chain performance is the SCOR model which is a processbased models. The model integrates three key elements in the management namely business process reengineering, benchmarking, and process measurement into a cross-functional framework in supply chain. The research was carried out with a case study at PT Sierad Produce, a feedmill industry in East Java, Indonesia. Based on supply chain business process mapping, resulted 22 design of metrics used for measuring Period I and Period II.

The result of measurement found increase of SCOR process performance by $5.3 \%$ and attributes performance by $5.6 \%$.
\end{abstract}

Keywords: performance measurement, supply chain, metrics, supply chain operations reference, SCOR.

\section{PENDAHULUAN}

Integrasi ekonomi kini tak bisa ditawar lagi. Siap tidak siap, Indonesia mesti berpartisipasi. Mulai dari integrasi di level regional hingga global. Kali ini yang didepan mata adalah bersatunya negara-negara di Asia Tenggara dalam wadah komunitas Ekonomi ASEAN (KEA). Pada tahun 2015, liberalisasi akan merata ke seluruh sektor perekonomian ASEAN. Hal itu akan ditandai dengan mengalirnya arus barang, jasa, investasi, tenaga kerja terampil, hingga perpindahan barang modal dari satu negara ke negara lain dengan pertimbangan efisiensi dan efektifitas. Peta persaingan akan berubah dari persaingan industri dalam satu negara menjadi persaingan industri regional ASEAN, dimana kinerja pengelolaan rantai pasok akan menjadi lebih strategis.

Penelitian ini dilakukan dengan studi kasus di PT Sierad Produce yang belum memiliki rancangan metrik pengukuran kinerja rantai pasok. Disamping itu, PT Sierad Produce memiliki keunikan pada proses pengadaan bahan baku untuk kebutuhan proses produksi. Proses pengadaan bahan baku berdasarkan skema pendanaan stock, yaitu suatu skema pembiayaan dimana pendana memberikan fasilitas kredit kepada PT Sierad Produce berdasarkan agunan dalam bentuk bahan baku yang berada dalam suatu gudang yang terkontrol secara independen. Permasalahan yang sering terjadi terkait dengan skema pendanaan stock adalah feed untuk kebutuhan produksi habis sementara belum ada suplai bahan baku dari Bagian Warehouse. Keterlambatan suplai bahan baku ini mengakibatkan penghentian sementara proses produksi sehingga terjadi kerugian kesempatan produksi (production opportunity loss) dan biaya start up untuk memulai kembali proses produksi paska penghentian sementara. Kejadian penghentian sementara proses produksi ini menggambarkan belum efektifnya kinerja pengelolaan rantai pasok di PT Sierad Produce yang menyebabkan inefisiensi.

Tujuan dilakukannya penelitian ini adalah : 1) mendapatkan rancangan pengukuran kinerja rantai pasok di PT Sierad Produce dengan model SCOR; 2) mengetahui kinerja rantai pasok PT Sierad Produce; 3 ) pembuatan rekomendasi usulan perbaikan untuk peningkatan kinerja rantai pasok di PT Sierad Produce. 


\section{KAJIAN PUSTAKA}

Untuk menciptakan manajemen kinerja yang efektif, diperlukan sistem pengukuran yang mampu mengevaluasi kinerja rantai pasok secara holistik (Pujawan dan Mahendrawathi, 2010). Metode yang digunakan untuk mengukur kinerja rantai pasok adalah Supply Chain Operational Reference (SCOR). SCOR dikembangkan oleh Supply Chain Council (SCC), suatu organisasi independen dan non profit yang didirikan pada tahun 1996 oleh global management - consulting firm, Pittiglio Rabin Todd \& McGrath (PRTM) dan market research firm, Advanced Manufacturing Research (AMR) di Cambridge, Massachusetts. Keanggotaan SCC pada awalnya adalah 69 perusahaan yang mendaftar secara sukarela. Saat ini ribuan perusahaan menjadi anggota SCC dan sudah menerapkan SCOR, diantaranya Exxon Mobil, Coca Cola, Delloite, Philips, SAP, Fujitsu dan Microsoft (www.supply-chain.org/scor). SCOR mengalami perkembangan sangat penting saat ini terutama pada perusahaan-perusahaan di Amerika Utara. Peningkatan juga terjadi di Asia dan Eropa dimana SCOR dapat mengidentifikasi kinerja rantai pasok secara menyeluruh untuk optimasi perusahaan (Maimaiti et al., 2011). SCOR merupakan alat untuk membuat perencanaan strategis yang memungkinkan manajer senior menyederhanakan kompleksitas suatu manajemen rantai pasok dan kemudian dijadikan acuan/standar untuk pengukuran kinerja berikutnya (Huan et al. 2004).

Penelitian-penelitian terdahulu tentang perancangan dan pengukuran kinerja rantai pasok model SCOR, diantaranya adalah : 1) A SCOR based approach for measuring a benchmarkable supply chain performance (Kocaoglu, 2013). Pada penelitian ini, pendekatan model SCOR digunakan untuk pengukuran kinerja rantai pasok untuk mendapatkan solusi konfik antara dekomposisi strategi top-down dengan proses implementasi bottom- up. Digunakan juga metode Analytical Hierarchy Process (AHP) untuk menganalisis hirarki metrik dan metode Techinique for Order Preference by Similarity to Ideal Solution (TOPSIS) untuk menghubungkan tujuan strategis hingga operasional. Keputusan-keputusan yang dihasilkan dari penelitian dapat diimplementasikan oleh Manager perusahaan manufaktur yang menjadi subyek penelitian;2) Modeling Research on Internal
Manufacturing Supply Chain Based on SCOR Model (Maimaiti et. al., 2011). Pada penelitian ini, dideskripsikan proses dasar rantai pasok perusahaan dan level proses SCOR yang dikombinasikan dengan karakteristik internal proses manufaktur dengan pendekatan model SCOR. Hasil penelitian dapat memberikan pertimbangan lebih baik terhadap kinerja perusahaan secara menyeluruh dan merealisasikan proses optimisasi perusahaan; 3) Perancangan dan Pengukuran Kinerja Rantai Pasok di Instalasi Farmasi Rumah Sakit PKU Muhammadyah Temanggung (Helia, 2011). Pada penelitian ini dilakukan perancangan pengukuran kinerja rantai pasok yang diterapkan untuk proses evaluasi dan perbaikan. Hasil penelitian adalah rancangan 32 (tiga puluh dua) metrik pengukuran kinerja dan dari hasil pengukuran, terdapat 5 (lima) metrik kinerja sebagai prioritas perbaikan perusahaan yaitu warehouse utilization, drugs availability rate, percentage of expired or damaged drugs, frequency of drugs procurement, and source employee reability: 4) Pengukuran dan Peningkatan Performansi Supply Chain dengan pendekatan model SCOR dan Lean Six Sigma di PT. Gunawan Dianjaya Steel, Tbk. (Primantara dan Supriyanto 2010). Pada penelitian ini diterapkan metode Lean Six Sigma dengan model SCOR. Model SCOR digunakan sebagai model pengukuran performansi supply chain PT.GDS sedangkan metode Lean Six Sigma untuk mendapatkan indikator performansi kritis. Hasil penelitian adalah identifikasi tiga indikator yang menjadi fokus perbaikan adalah inventory days of supply (supply chain asset), make cycle time(responsiveness) dan on time delivery (reliability); 5) Penelitian Pengukuran Kinerja Manajemen Rantai Pasok dengan Pendekatan SCOR di PT Indocement Tunggal Prakarsa Tbk. (Mutakin 2010). Pada penelitian ini dilakukan pemetaan rantai pasok level 1 (kriteria perfect order fulfillment, order fulfillment cycle time, cost of good sold dan cash-to-cash cycle time) yang kemudian di turunkan ke pemetaan level 2 dan pemetaan level 3. Hasil penelitian adalah kinerja rantai pasok perusahaan untuk kriteria perfect order fulfillment, order fulfillment cycle time, cost of good sold dan cash-to-cash cycle time yang selanjutnya dibandingkan dengan standar APQC (American Productivity and Quality Center) untuk menetapkan indikator kritis perbaikan; 6) Penelitian-penelitian lain sebagaimana ditulis Helia (Helia, 2011) yaitu di perusahaan manufaktur PT 
Sion Birdnest (Magdalena, 2005) dan PT Gillette (Dolan, 2004) membuktikan bahwa pengukuran kinerja rantai pasok dapat menggerakkan perbaikan berkelanjutan dan penghematan biaya.

\section{Konsep Rantai Pasok dan Manajemen Rantai Pasok}

Rantai pasok adalah jaringan perusahaanperusahaan yang bekerja untuk menciptakan dan menghantarkan suatu produk ke tangan pemakai akhir secara bersama-sama. Perusahaan-perusahaan tersebut biasanya pemasok, pabrik, distributor, toko atau ritel dan perusahaan-perusahaan pendukung seperti perusahaan jasa logistik (Pujawan dan Mahendrawathi, 2010). Sebuah produk akan sampai ke tangan pemakai akhir, setelah setidaknya mengalami beberapa proses dari pencarian bahan baku, proses produksi dan proses distribusi atau transportasi. Proses-proses ini akan melibatkan berbagai pihakyang berhubungan antara satu dengan yang lain yang biasanya disebut dengan rantai pasok (Sheikh, 2002). Jadi rantai pasok mencakup semua aktifitas yang berhubungan dengan aliran transformasi barang dan jasa dari bahan baku menjadi barang jadi kepada pelanggan. Dengan penjelasan ini maka rantai pasok merupakan aliran fisik barang atau jasa, sedangkan manajemen rantai pasok merupakan metode, alat atau pendekatan pengelolaan aliran fisik yang menekankan pada metode terintegrasi dengan semangat kolaborasi (Pujawan dan Mahendrawathi 2010). Pada suatu rantai pasok biasanya ada 3 (tiga) macam aliran yang harus dikelola, yaitu pertama adalah aliran barang dari hulu ke hilir. Kedua adalah aliran uang dan sejenisnya dari hilir ke hulu dan yang ketiga adalah aliran informasi dari hulu ke hilir dan dari hilir ke hulu. Prinsip Manajemen Rantai Pasok pada dasarnya merupakan sinkronisasi dan koordinasi aktifitas-aktifitas yang terkait dengan aliran internal/produk baik yang ada dalam suatu organisasi maupun antar organisasi.

\section{Lingkup Manajemen Rantai Pasok}

Manajemen rantai pasok terdiri atas tiga unsur yang saling terkait satu sama lain (Miranda dan Amin, 2006), yaitu : 1) struktur jaringan rantai pasok, yaitu jaringan kerja anggota dan hubungan dengan anggota rantai pasok lainnya. Anggota rantai pasok meliputi semua perusahaan dan organisasi yang berhubungan dengan perusahaan lokal, baik secara langsung maupun tidak langsung melalui pemasok atau pelanggannya dari point of origin hingga point of consumption; 2) proses bisnis rantai pasok, yaitu aktifitas-aktifitas yang menghasilkan nilai keluaran tertentu bagi pelanggan, meliputi Customer Relationship Management (CRM), Customer Service Management (CSM), Demand Management, Customer order fulfillment (COF), Manufacturing flow management (MFM), Pengembangan produk dan komersialisasi, dan Returns; 3) komponen manajemen rantai pasok berupa peubah-peubah manajerial dimana proses bisnis disatukan dan disusun sepanjang rantai pasok.

Rantai pasok melibatkan variasi tahapantahapan (Chopra dan Mendl (2007) yang terdiri dari : 1) Rantai 1 (Pemasok), merupakan sumber yang menyediakan bahan pertama dimana mata rantai penyaluran barang dimulai. Bahan pertama ini dapat dalam bentuk bahan baku, bahan mentah, bahan penolong, bahan dagangan, penggabungan, dan sebagainya; 2) Rantai 2 (Manufaktur), melakukan proses produksi, pabrikasi, merakit dan menyelesaikan barang hingga menjadi produk jadi; 3) Rantai 3 (Distributor), barang yang sudah selesai dipabrikasi akan didistribusikan ke gudang atau disalurkan ke gudang milik distributor atau pedagang besar dalam jumlah besar dan pada waktunya nanti pedagang besar menyalurkan dalam jumlah yang lebih kecil kepada retailer (pengecer); 4) Rantai 4 (Retailer), pengecer berfungsi sebagai rantai pasok yang ada di antara distributor yang pada umumnya pedagang besar ke pedagang kecil (pengecer). Pengecer berupa gerai seperti toko, warung, departement store, supermarket, hypermarket, koperasi, mal, club stores, dan sebagainya; 5) Rantai 5 (Pelanggan), dari distributor atau pengecer, barang ditawarkan langsung kepada pelanggan sebagai pengguna barang tersebut. Akhir dari mata rantai pasok adalah pada saat produk sampai kepada orang yang menggunakan atau memakai produk tersebut. Kelima rantai pasok di atas sebagaimana terlihat pada Gambar 1. 


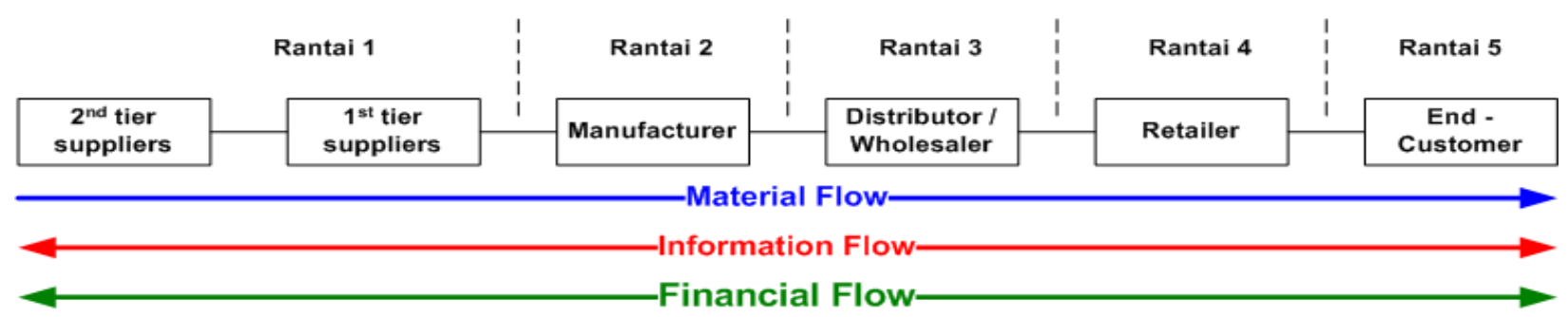

Gambar 1 : Hubungan proses rantai pasok

\section{Konsep Pengukuran Kinerja}

Beberapa sistem pengukuran kinerja yang digunakan saat ini, memiliki kelompok pendukung masing-masing. Misalnya, model Balanced Scorecard, Performance Prism, dan The Cambridge Performance Measurement Process dirancang untuk implementasi bisnis secara luas; sedangkan model Total Performace Measurement (TPM) Process, 7-steps TPM Process, dan Total Measurement Development Method (TMDM) adalah khusus untuk struktur berbasis Tim. Tidak ada versi tunggal dari model yang dapat diterima secara universal. Keragaman dan keunikan dari kebutuhan perusahaan yang berbeda-beda menunjukkan bahwa tidak ada satu ukuran pendekatan yang cocok untuk semua pekerjaan (Gamble, et. al., 2007). Demikian pula halnya dengan model Supply Chain Operation Reference (SCOR), dirancang untuk pengukuran kinerja rantai rantai pasok

Pengukuran kinerja rantai pasok perlu dilakukan untuk mengetahui apakah selama pelaksanaan kegiatan rantai pasok terdapat deviasi dari rencana yang telah ditentukan, atau apakah hasil kinerja rantai pasok dapat dilakukan sesuai jadwal waktu yang ditentukan, atau apakah hasil kinerja rantai pasok telah tercapai sesuai dengan yang diharapkan. Untuk melakukan pengukuran tersebut, diperlukan kemampuan untuk mengukur kinerja sehingga diperlukan adanya ukuran kinerja. Pengukuran kinerja hanya dapat dilakukan terhadap aktifitas yang nyata dan terukur. Apabila kinerja tidak dapat diukur maka tidak dapat dikelola. Untuk dapat memperbaiki kinerja, perlu diketahui seperti apa kinerja pada saat ini. Apabila deviasi kinerja dapat diukur maka kinerja dapat diperbaiki (Wibowo, 2011). Pengukuran kinerja rantai pasok hanya berkepentingan mengukur apa yang penting dan relevan. Untuk itu, perlu jelas tentang apa yang dikatakan penting dan relevan sebelum menentukan ukuran apa yang harus digunakan. Hal-hal yang diukur tergantung pada apa yang dianggap penting oleh stakeholders dan pelanggan. Pengukuran mengatur keterkaitan antara strategi berorientasi pelanggan dan tujuan dengan tindakan (Wibowo, 2011). Tiga kriteria yang dapat digunakan untuk menilai keefektifan dari sistem pengukuran kinerja (Olsen et al. 2007) yaitu : 1) keterkaitan; 2) perbaikan terus-menerus; dan 3) pengawasan proses. Dengan demikian pengukuran kinerja rantai pasok (supply chain performance measurement) mengandung makna suatu proses atau sistem penilaian pengelolaan berbagai kegiatan rantai pasok mengacu kepada suatu standar pengukuran tertentu untuk mengontrol aktifitas rantai pasok dan hasilnya sebagai masukan evaluasi perbaikan dalam rangka meningkatkan daya saing perusahaan. Pengukuran kinerja saja tidaklah cukup namun perlu adanya penetapan target. Target-target kinerja didesain dan ditetapkan untuk menjangkau dan mendorong organisasi agar mencapai tujuan-tujuan strategiknya. Salah satu acuan untuk menetapkan target kinerja pada masa yang akan datang adalah menggunakan kinerja masa lalu. Kecenderungan masa lalu dapat dikembangkan untuk pengembangan kinerja dimasa yang akan datang. Tujuan-tujuan strategik dapat juga menjadi pendorong untuk mencapai target dimasa yang akan datang. Acuan lain untuk penetapan target adalah melakukan benchmarking terhadap praktek-praktek terbaik dalam dunia bisnis Menurut (Gaspersz, 2011).

Sejalan dengan filosofi manajemen rantai pasok yang mendorong terjadinya integrasi antar fungsi, maka pendekatan berdasarkan proses banyak digunakan untuk mengukur kinerja rantai pasok. Untuk merancang sistem pengukuran pengukuran kinerja, model Chan dan Li (Pujawan dan Mahendrawathi, 2010) menyarankan 7 (tujuh) langkah, yaitu: 1) Identifikasi dan hubungkan semua proses yang terlibat baik yang terjadi di dalam maupun di luar organisasi. Tentunya disini perlu 
dipilih terlebih dahulu domain proses yang spesifik. Misalnya, proses pengadaan dan transportasi, proses pemenuhan pesanan dari pelanggan, proses perancangan produk baru, dan sebagainya; 2) Definisikan dan batasi proses inti. Definisi dan batasan ini diperlukan karena tidak semua proses yang ada pada supply chain membutuhkan perhatian yang sama dari manajemen. Di samping itu tidak semuanya memberikan nilai tambah. Pada tahap ini perlu didefinisikan proses-proses inti serta batasan sampai dimana proses-proses tersebut akan dianalisa; 3) Tentukan misi, tanggung jawab, dan fungsi dari proses inti. Misi, tanggung jawab, dan fungsi dari tiap proses harus jelas. Misalnya misi bagian pengadaan adalah untuk membeli material yang tepat dari suplier sehingga kegiatan produksi bisa berlangsung dengan lancar. Tanggung jawabnya bisa diwujudkan dalam pernyataan yang lebih detail seperti menjaga pasokan secara berkesinambungan dengan harga murah dan kualitas bagus, meminimumkan investasi persediaan, memelihara supply base, dan menjalin hubungan yang tepat dengan pemasok. Langkah ini perlu dilakukan sebagai acuan untuk menentukan mana aktifitas atau proses yang tidak memberikan value-added sehingga bisa dieliminasi. Misi dan tanggung jawab yang jelas juga diperlukan untuk menguraikan proses-proses inti menjadi sub-proses pada langkah 4 berikut; 4) Uraikan dan identifikasi sub-proses. Setiap proses inti biasanya merupakan agregasi dari sejumlah sub-proses. Oleh karena itu, dalam pendekatan proses, setiap proses inti perlu diuraikan menjadi sub-proses yang menyusunnya. Sebagai contoh, proses pembelian material melibatkan sub-proses: pengecekan stock yang ada, penentuan kuantitas dan tanggal kebutuhan, pembuatan dan pengiriman $\mathrm{PO}$, pemrosesan pesanan oleh pemasok, pengiriman, receiving dan incoming inspection, penyimpanan di gudang, penagihan dan pembayaran. Setiap sub-proses di atas membutuhkan keterlibatan dari satu atau lebih fungsi baik di dalam perusahaan maupun di luar. Karena kita berbicara dalam konteks supply chain, semestinya proses-proses yang di tinjau tidak hanya yang dilakukan oleh internal organisasi, tetapi juga yang dilakukan pihak lain. Sebagai contoh, kegiatan pemrosesan pesanan dan penagihan dilakukan oleh suplier, kegiatan pengiriman mungkin dilakukan oleh perusahaan jasa pengiriman. Namun seperti yang dijelaskan pada langkah 2 tadi, perlu dibuat batasan sejauh mana analisa akan dilakukan; 5) Tentukan tanggung jawab dan fungsi sub-proses. Sama halnya seperti proses-proses inti, tanggung jawab dan fungsi masing-masing sub-proses juga perlu terdefinisi dengan jelas. Tentu saja tanggung jawab dan fungsi tiap sub-proses ini lebih operasional dan spesifik dibandingkan dengan tanggung jawab dan fungsi proses-proses inti; 6) Uraikan lebih lanjut subproses menjadi aktivitas. Langkah ini tidak selalu perlu dilakukan, namun biasanya bisa bermanfaat karena sub-proses bisa jadi masih terlalu umum dan sulit diukur. Disamping itu, pemisahan antara aktivitas mana yang memberikan niali tambah dan aktifitas mana yang tidak baru bisa dilakukan kalau tiap-tiap proses sudah diuraikan cukup detail sampai ke aktifitas-aktifitas elementer; dan 7) Hubungkan target antar hirarki mulai dari proses sampai ke aktifitas. Manajemen puncak biasanya memiliki target yang umum. Misalnya dalam tiga tahun ingin mengurangi order fulfilment lead time menjadi $60 \%$ dari yang sekarang. Target ini tentu harus bisa diterjemahkan menjadi targettarget yang lebih spesifik oleh manajer madya. Dengan mengetahui semua sub-proses dan aktifitas elementer yang terlibat dalam memenuhi order dari pelanggan serta berapa waktu yang dibutuhkan oleh masing-masing sub-proses maupun aktivitas elementer saat ini, perusahaan bisa lebih jelas menentukan langkah-langkah untuk mencapai target tersebut serta memonitor progress dari waktu ke waktu. Gambar 2, mengilustrasikan struktur umum langkah-langkah melakukan dekomposisi dalam merancang sistem pengukuran kinerja rantai pasok yang berdasarkan proses. Ke-tujuh langkahlangkah di atas merupakan proses bisnis yang dapat dipetakan dengan pengembangan representasi grafik hubungan orgnisasional dan/atau aktifitasaktfitas suatu proses. 


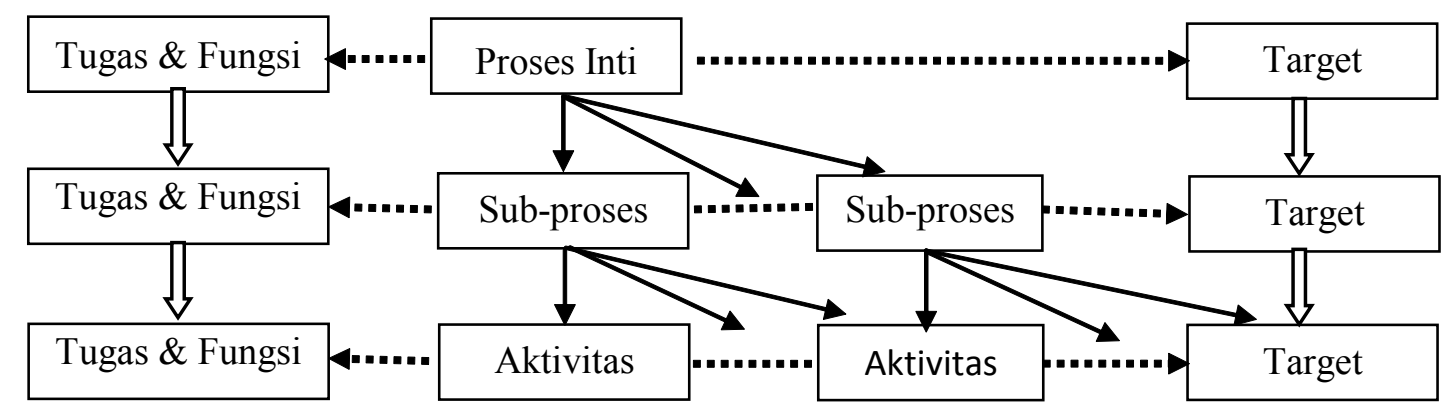

Gambar 2: Dekomposisi proses dalam pengembangan sistem pengukuran kinerja supply chain berdasarkan proses model Chan \& Li [Sumber: Pujawan dan Mahendrawathi (2010)].

\section{Konsep SCOR}

SCOR mengintegrasikan tiga elemen utama dalam manajemen yaitu bussiness process reengineering, benchmarking dan measurement process kedalam kerangka lintas fungsi dalam rantai pasok. Ketiga elemen tersebut memiliki fungsi sebagai berikut: 1) Bussiness process reengineering pada hakekatnya menangkap proses kompleks yang terjadi saat ini (as is) dan mendefinisikan proses yang diinginkan (to be); 2) Benchmarking adalah kegiatan untuk mendapatkan data kinerja operasional dari perusahaan sejenis. Target internal kemudian ditentukan berdasarkan kinerja best in class yang diperoleh; 3) Measurement process berfungsi untuk mengukur. mengendalikan dan memperbaiki proses-proses rantai pasok.

\section{Lingkup SCOR}

Lingkup SCOR membentang mulai dari supliernya suplier (supplier's supplier) hingga pelanggannya pelanggan (customer's customer) sebagaimana terlihat pada Gambar 3. Proses ini termasuk seluruh interaksi pelanggan mulai dari pemesanan (order entry) hingga invoice dibayar (invoice paid); transaksi seluruh produk (fisik barang dan jasa) termasuk peralatan, leveransir, sparepart, software dan seluruh interaksi pasar dari perhitungan kebutuhan agregat (aggregate demand) hingga masing-masing pesanan dipenuhi.

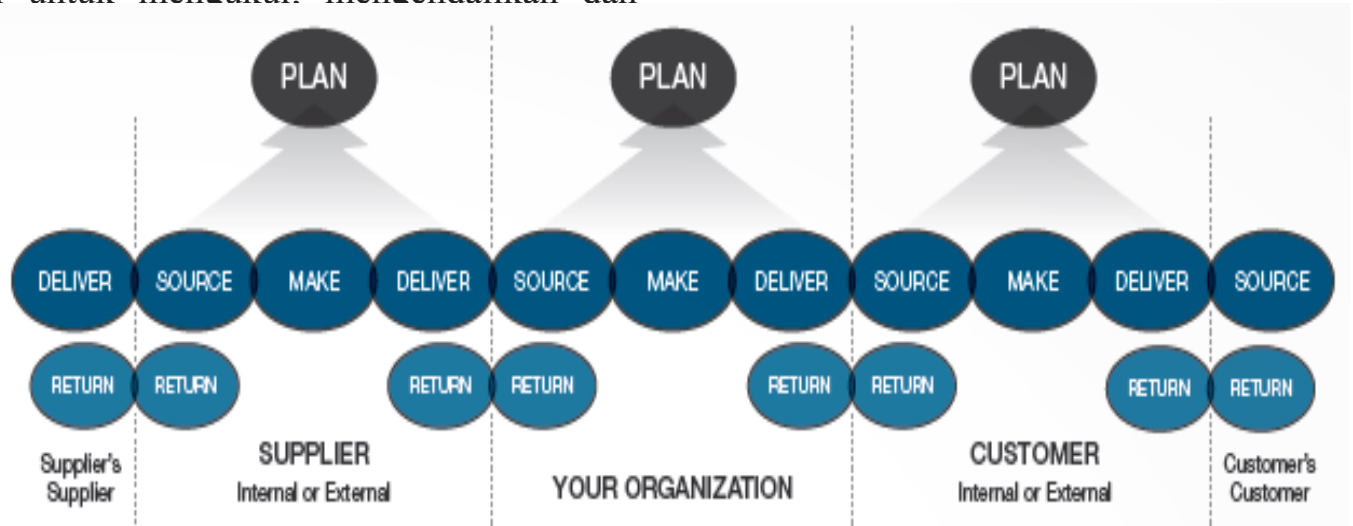

Gambar 3 : Cakupan SCOR dan lima proses inti rantai pasok model SCOR

\section{Proses SCOR}

SCOR terdiri dari 5 (lima) proses inti yang membentuknilai hubungan antara para pelaku dalam jaringan rantai pasok, yaitu : 1) Plan (perencanaan) : Menyeimbangkan sumber daya (resources) dengan permintaan dan rencana-rencana yang telah ditetapkan/dikomunikasikan untuk seluruh rantai pasok, termasuk Return, dan eksekusi proses Source, Make dan Deliver; mengelola aturan bisnis, kinerja rantai pasok, mengkonfigurasi perencanaan, pemenuhan persyaratan terhadap suatu ketentuan dan resiko rantai pasok; menyesuaikan rencana Unit rantai pasok dengan rencana keuangan; 2) Source (sumber daya) : Menjadwalkan pengiriman, penerimaan, verifikasi, pemindahan produk dan pemberian otorisasi pembayaran kepada supplier; mengidentifikasi dan menyeleksi sumber-sumber pasokan jika tidak dapat ditentukan di awal, seperti produk engineer-to-order; mengelola aturan bisnis, menilai kinerja suplier dan memelihara data. Mengelola persediaan, asset-aset, produk masuk, jaringan suplier, kebutuhan ekspor/impor, 
kesepakatan dengan suplier dan sumber resiko rantai pasok; 3) Make (pembuatan) : Menjadwalkan produksi, permasalahan produk, kegiatan produksi dan pengujian, pengemasan, pemajangan produk dan mengeluarkan produk untuk dikirim; memfinalisasi rekayasa untuk produk engineerto-order; mengelola aturan, kinerja, data, produk setengah jadi, peralatan dan fasilitas, transportasi, jaringan produksi, pemenuhan peraturan untuk produksi, dan pembuatan resiko rantai persediaan; 4) Deliver (pengiriman): Seluruh tahap pengelolaan mulai dari proses permintaan pelanggan dan penawaran untuk menjalankan pengiriman dan memilih perusahaan pengangkutan; pengelolaan gudang mulai dari penerimaan hingga mengangkut produk untuk dimuat dan dikapalkan (dikirim); menerima dan memverifikasi produk di lokasi customer dan juga pemasangan; menagih pelanggan; mengelola ketentuan bisnis proses Deliver, kinerja, informasi, persediaan produk jadi, asset-aset, transportasi, masa hidup produk (product life cycle), permintaan import/export, dan resiko Deliver pada rantai pasok; 5) Return (pengembalian) : Seluruh tahap pemeliharaan pengembalian, perbaikan dan pembongkaran mulai dari sumber, identifikasi kondisi produk, penempatan produk, otorisasi permintaan pengembalian produk, jadwal pengiriman produk dan pengembalian produk cacat, pengiriman, otorisasi pengembalian produk, jadwal penerimaan pengembalian, penerimaan produk dan pemindahan produk cacat; seluruh tahap pengembalian produk sisa dimulai dari sumber, identifikasi kondisi produk, penempatan produk, otorisasi permintaan pengembalian produk, jadwal pengiriman produk dan pengembalian produk sisa, pengiriman, otorisasi pengembalian produk, jadwal penerimaan pengembalian, penerimaan produk dan pemindahan produk sisa; mengelola ketentuan bisnis proses Return, kinerja, pengumpulan data, asset-aset, transportasi, konfigurasi jaringan, pemenuhan persyaratan dan resiko rantai pasok Return.

\section{Kinerja SCOR}

SCOR terdiri dari 2 (dua) jenis elemen, yaitu atribut kinerja dan metrik. Atribut kinerja adalah sekelompok metrik yang digunakan untuk menyatakan strategi. Atribut kinerja dikelompokkan menjadi 2 (dua) katagori yaitu Customer Facing dan Internal Facing yang terdiri dari 5 (lima) atribut, yaitu : 1) Reliability adalah kehandalan sistem rantai pasok yang berkaitan dengan ketepatan produk, tempat, jumlah dan dokumen; 2) Responsiveness adalah kecepatan sistem rantai pasok untuk menyediakan produk; 3) Supply Chain Flexibility adalah Kemampuan sistem rantai pasok untuk merespon permintaan pasar atau memelihara keunggulan bersaing; 4) Cost adalah biaya-biaya yang timbul berkaitan dengan operasional sistem rantai pasok; 5) Asset adalah tingkat efektifitas dari organisasi dalam mengelola asset untuk mendukung kepuasan permintaan pelanggan.

Suatu atribut tidak dapat diukur, namun digunakan untuk menetapkan strategi. Metrik mengukur kemampuan rantai pasok untuk mencapai atribut-atribut tersebut. SCOR terdiri dari 10 (sepuluh) Metrik Level 1, yaitu : 1) Perfect Order Fulfillment (POF) adalah Jumlah order yang terkirim "on-time \& in full" sesuai dengan permintaan pelanggan atau kontrak/ komitmen dan kesesuaian dokumen-dokumen PO, invoice serta penerimaan (receipt) dibagi dengan jumlah total order; 2) Order Fulfillment Cycle Time (OFCT) adalah jumlah waktu (hari) yang dibutuhkan sejak dari order diterima sampai produk diterima di tempat pelanggan; 3) Upside Supply Chain Flexibility (USCF) adalah jumlah waktu (hari) yang dibutuhkan sistem rantai pasok untuk merespon peningkatan produksi dengan asumsi tidak ada kendala dalam bahan baku; 4) Upside Supply Chain Adaptability (USCA) adalah persentase kenaikan jumlah maksimum terkirim yang dapat dipertahankan (sustainable) dan dapat dicapai dalam 30 hari; 5) Downside Supply Chain Adaptability (DSCA) adalah jumlah pengurangan kuantitas yang dipesan dalam 30 hari sebelum pengiriman tanpa persediaan atau biaya tambahan; 6) Total Supply Chain Management Cost (TSCM) adalah biaya langsung dan tak langsung untuk proses perencanaan, sourcing dan pembuatan produk serta jasa; 7) Cost of Goods Sold (CGS) adalah biaya langsung (direct cost) untuk material dan biaya upah yang dibutuhkan untuk membuat produk; 8) Cash-to-cash Cycle Time (CCCT) adalah jumlah hari dibutuhkan untuk menagih invoice, dari saat modal kerja digunakan; 9) Return on Supply Chain Fixed Assets (RSCFA) adalah return yang diperoleh dari modal yang diinvestasikan pada aset tetap dalam rantai pasok; 10) Return on Working Capital (ROWC) adalah 
besarnya investasi relatif kepada posisi modal kerja perusahaan dibandingkan dengan pendapatan yang diperoleh dari rantai pasok. Hubungan antara
Metrik SCOR Level 1 dan Atribut Kinerja adalah sebagaimana terlihat pada Tabel 1.

Tabel 1 : Atribut Kinerja dan Metrik Level 1 SCOR

\begin{tabular}{|c|c|c|c|c|c|}
\hline \multirow{3}{*}{ Metrik SCOR Level 1} & \multicolumn{5}{|c|}{ Performance Attribute } \\
\hline & \multicolumn{3}{|c|}{ Customer Facing } & \multicolumn{2}{|c|}{ Internal facing } \\
\hline & Reliability & $\begin{array}{c}\text { Responsive- } \\
\text { ness }\end{array}$ & Agility & Cost & Asset \\
\hline Perfect Order Fulfillment & $\sqrt{ }$ & & & & \\
\hline Order Fulfillment Cycle Time & & $\sqrt{ }$ & & & \\
\hline Upside Supply Chain Flexibility & & & $\sqrt{ }$ & & \\
\hline Upside Supply Chain Adaptability & & & $\sqrt{ }$ & & \\
\hline Downside Supply Chain Adaptability & & & $\sqrt{ }$ & & \\
\hline Supply Chain Management Cost & & & & $\sqrt{ }$ & \\
\hline Cost of Good Sold & & & & $\sqrt{ }$ & \\
\hline Cash to Cash Cycle Time & & & & & $\sqrt{ }$ \\
\hline Return on Supply Chain Fixed Asset & & & & & $\sqrt{ }$ \\
\hline Return on Working Capital & & & & & $\sqrt{ }$ \\
\hline
\end{tabular}

\section{METODE PENELITIAN}

Jenis penelitian ini adalah Observasional Deskriptif dengan pendekatan Studi Kasus dengan obyek penelitian adalah aktifitas rantai pasok di PT Sierad Produce Tbk. yang meliputi proses perencanaan inventory, pengadaan pembelian, pengapalan, penerimaan, pergudangan, produksi, stock financing, penjualan dan retur. Data-data yang dibutuhkan untuk penelitian adalah datadata yang terkait dengan aliran bahan baku, aliran finansial dan aliran informasi aktifitas rantai pasok di PT Sierad Produce Tbk.

Metode pengumpulan data dilakukan dengan cara observasi dan pengamatan langsung dilapangan untuk mengidentifikasi proses bisnis rantai pasok untuk perancangan kinerja rantai pasok dan pelaksanaan pengukuran kinerja rantai pasok; wawancara untuk klarifikasi proses bisnis rantai pasok; opini pakar untuk mendapatkan metrik prioritas pengukuran kinerja rantai pasok; dan dokumen-dokumen yang terkait dengan aktifitas rantai pasok.

Variabel-variabel yang digunakan pada penelitian ini adalah variabel bebas yaitu, metrik pengukuran kinerja rantai pasok atau metrik aktifitas hasil rancangan; variabel kendali (controlled variable), yaitu target kinerja masingmasing metrik kinerja rantai pasok; dan variabel tergantung (dependen), yaitu kinerja proses SCOR (Plan, Source, Make, Deliver, dan Return), Metrik SCOR Level 1 (Perfect Order Fulfillment, Order Fulfillment Cycle Time, Upside Supply Chain Flexibility, Upside Supply Chain Adaptability, Downside Supply Chain Adaptability, Total Supply Chain Management Cost, Cost of Goods Sold, Cash-to-cash Cycle Time, Return on Supply Chain Fixed Assets dan Return on Working Capital), dan Atribut kinerja SCOR (Realibility, Responsiveness, Agility, Cost, dan Asset).

Penelitian ini terdiri dari 2 (dua) tahap yaitu tahap perancangan metrik dan tahap pengukuran kinerja. Pada tahap perancangan metrik, langkahlangkah yang dilakukan adalah Penjabaran proses bisnis dan proses bisnis rantai pasok model Chan \& Li (Langkah 1); Pengkonfigurasian dan pemetaan geografis rantai pasok mulai dari pasokan bahan baku dari pemasok hingga realisasi produk jadi diterima pelanggan (Langkah 2); Pelingkupan proses bisnis rantai pasok ke dalam Proses SCOR (Langkah 3); Pembuatan Metrik (Langkah 4); dan Validasi Metrik (Langkah 5). Pada tahap pengukuran kinerja, metrik yang sudah divalidasi digunakan untuk mengukur kinerja rantai pasok. Pengkuran dilakukan 2 (dua) kali yaitu Periode I dan Periode II. Hasil pengukuran Periode I digunakan sebagai benchmark untuk pengukuran Periode II. 


\section{HASIL PENELITIAN DAN PEMBAHASAN PERANCANGAN METRIK}

Langkah 1 : Proses bisnis PT Sierad Produce Tbk. meliputi 3 (tiga) tahapan utama yaitu Product Development (pengembangan produk), Production (Produksi) dan Marketing (Pemasaran). Berdasarkan informasi tentang keinginan konsumen yang diperoleh dari riset pasar, didesain produk untuk memenuhi keinginan pasar tersebut. Desain produk telah menetapkan model dan spesifikasi yang harus diikuti bagian produksi. Selanjutnya dilakukan pengadaan kebutuhan bahan baku, proses produksi hingga dihasilkan produk jadi. Produk selanjutnya dipromosikan dan dijual kepada konsumen. Keseluruhan proses didukung fungsi Finance dan Accounting dalam mengelola kebutuhan modal kerja baik yang berasal dari internal perusahaan maupun kolaborasi dengan eksternal perusahaan. Proses bisnis PT Sierad Produce Tbk. Unit Feed Mill Sidoarjo sebagaimana pada Gambar 1.

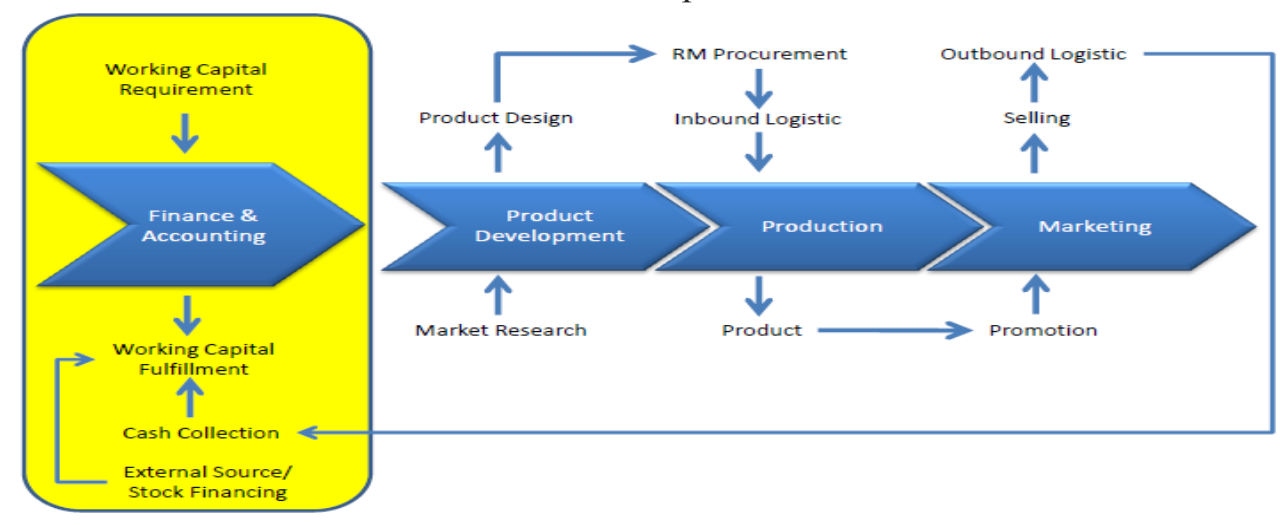

Gambar 4 : Proses Bisnis PT Sierad Produce Tbk.

Sedangkan pada proses bisnis rantai pasok, terdiri dari 9 (Sembilan) proses yaitu : 1) Perencanaan Inventory; 2) Pengadaan Pembelian; 3) Pengapalan; 4) Penerimaan; 5) Pergudangan; 6) Produksi; 7) Stock financing; 8) Penjualan; dan 9) Retur. Masing-masing proses bisnis rantai pasok didekomposisi menjadi sub proses dan dihasilkan 132 sub proses;

Langkah 2 : Pengkonfigurasian dan pemetaan geografis rantai pasok, dihasilkan diagram alir aktifitas rantai pasok, mulai dari supplier hingga distributor. Raw material impor (Meat Bon Meal, FTM, Soya Bean Meal dan Corn Gluten Meal) diantaranya diimpor dari Amerika dan India, dibawa menggunakan kapal laut menuju pelabuhan Tanjung Perak Surabaya. Setelah kapal tiba di pelabuhan
Tanjung Perak Surabaya, dilakukan pembongkaran muatan ke atas truk-truk pengangkut dan dibawa (trucking) menuju lokasi PT Sierad Produce. Setelah raw material tiba di lokasi PT Sierad Produce Tbk. Unit Feed Mill Sidoarjo, dilakukan proses pergudangan dan produksi. Produk yang dihasilkan adalah Pakan Ternak (kode B101, T204 dan BSG100) selanjutnya dikemas dan disimpan di gudang produk menunggu proses distribusi atau pengiriman ke distributor. Berdasarkan jadwal pengiriman dari Sales, Warehouse mempersiapkan truk untuk distribusi ke wilayah Jawa Timur, Jawa Tengah, Bali dan Makasar sedangkan untuk distribusi ke wilayah Sulawesi digunakan kontainer untuk selanjutnya dideliveri menggunakan kapal. Konfigurasi aliran rantai pasok sebagaimana dapat dilihat pada Gambar 4.

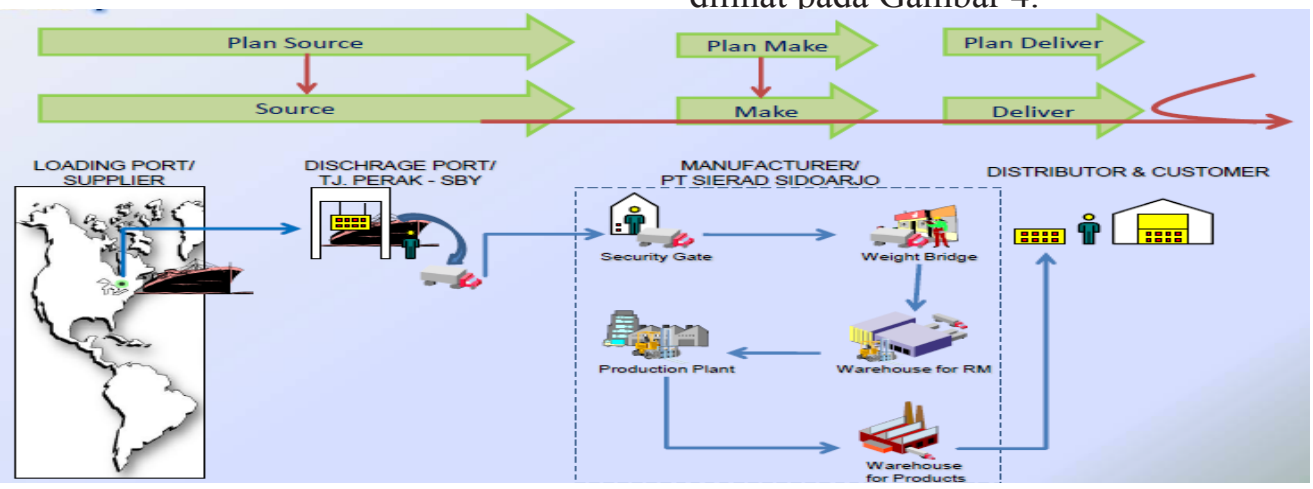


Gambar 4 : Konfigurasi aliran rantai pasok PT Sierad Produce

Langkah 3 : Pelingkupan proses bisnis rantai pasok ke dalam proses SCOR, masing-masing sub-proses dikelompokkan kedalam Proses SCOR Level 3 (unsur-unsur proses SCOR), selanjutnya dikomposisikan kedalam Proses SCOR Level 2 (tipe proses SCOR), kemudian dikomposisi kedalam Proses SCOR Level 1 (Plan, Source, Make, Deliver dan Return). Sebagai contoh sebagaimana terlihat pada Tabel 2.

Tabel 2 : Pelingkupan Proses Bisnis Rantai Pasok kedalam Model SCOR

\begin{tabular}{|c|c|c|c|c|c|c|}
\hline \multirow{2}{*}{ NO. } & \multirow{2}{*}{$\begin{array}{l}\text { PROSES BISNIS } \\
\text { RANTAI PASOK }\end{array}$} & \multirow{2}{*}{ SUB PROSES/AKTIFITAS } & \multicolumn{4}{|c|}{ PROSES SCOR } \\
\hline & & & \begin{tabular}{|l} 
LEVEL 1 \\
\end{tabular} & LEVEL 2 & LEVEL 3 & \\
\hline \multirow[t]{9}{*}{1.} & \multirow[t]{9}{*}{ Perencanaan Inventory } & a1. Perencanaan Penjualan & Plan & Plan Supply Chain & $\begin{array}{l}\text { Idendify, prioritize, \& Aggregate } \\
\text { Supply Chain Requirements. }\end{array}$ & $\mathrm{P} 1.1$ \\
\hline & & a2. Pengusulan Target Penjualan & Plan & Plan Supply Chain & $\begin{array}{l}\text { Balance Supply Chain Resources } \\
\text { with Supply Chain Requirements. }\end{array}$ & $\mathrm{P} 1.3$ \\
\hline & & a3. Penetapan Target Penjualan & Plan & Plan Supply Chain & $\begin{array}{l}\text { Establish \& Communicate Supply- } \\
\text { Chain Plans. }\end{array}$ & $\mathrm{P} 1.4$ \\
\hline & & a4. Perencanaan Produksi & Plan & Plan Make & $\begin{array}{l}\text { Idendify, prioritize, \& Aggregate } \\
\text { Production Requirements. }\end{array}$ & P3.1 \\
\hline & & a5. Penjadwalan Produksi & Plan & Plan Make & $\begin{array}{l}\text { Idendify, prioritize, \& Aggregate } \\
\text { Production Requirements. }\end{array}$ & P3.1 \\
\hline & & $\begin{array}{l}\text { a6. Perencanaan Kebutuhan Raw } \\
\text { Material }\end{array}$ & Plan & Plan Make & $\begin{array}{l}\text { Identify, assess, \& Aggregate } \\
\text { Production Resources. }\end{array}$ & P3.2 \\
\hline & & a7. Pembuatan Bill of Material & Plan & Plan Make & $\begin{array}{l}\text { Balance Production Resources with } \\
\text { Production Requirements. }\end{array}$ & P3.3 \\
\hline & & a8. Penetapan Bill of Material & Plan & Plan Make & Establish Production Plans. & P3.4 \\
\hline & & a9. Update Data Inventory Plan & Plan & Plan Make & Establish Production Plans. & P3.4 \\
\hline
\end{tabular}

Langkah 4 : Metrik dibuat berdasarkan pelingkupan proses bisnis rantai pasok kedalam Proses SCOR, masing-masing sub proses atau kelompok sub proses dirancang metrik pengukuran kinerja rantai pasok dan dihasilkan 59 rancangan metrik. Rancangan metrik selanjutnya divalidasi menggunakan Kuisioner Tingkat Kepentingan Metrik dari opini pakar, yaitu Bussiness Unit Head, GM Production dan Financial Controller. Skor penilaian yang digunakan adalah skala Likert dengan nilai ordinal $1-5$, dimana : Skor $1=$ Metrik sangat tidak penting; Skor 2 = Metrik tidak penting; Skor 3 = Metrik cukup penting; Skor $4=$ Metrik penting; Skor $5=$ Metrik sangat penting. Opini dari 3 (tiga) pakar selanjutnya dibuat rerata dan dikonfirmasikan dalam forum diskusi untuk finalisasi validasi metrik. Metrik hasil validasi yang digunakan untuk pengukuran adalah skor rerata per metrik $\geq 3$, sedangkan skor rerata per metrik $<3$ tidak digunakan untuk pengukuran. Jumlah rancangan Metrik hasil validasi adalah 22 metrik dan selanjutnya dikelompokkan kedalam Proses SCOR dan Atribut Kinerja sebagaimana dapat dilihat pada Tabel 3.

Tabel 3 : Matrik Hubungan Metrik Aktifitas dengan Proses SCOR dan Atribut Kinerja

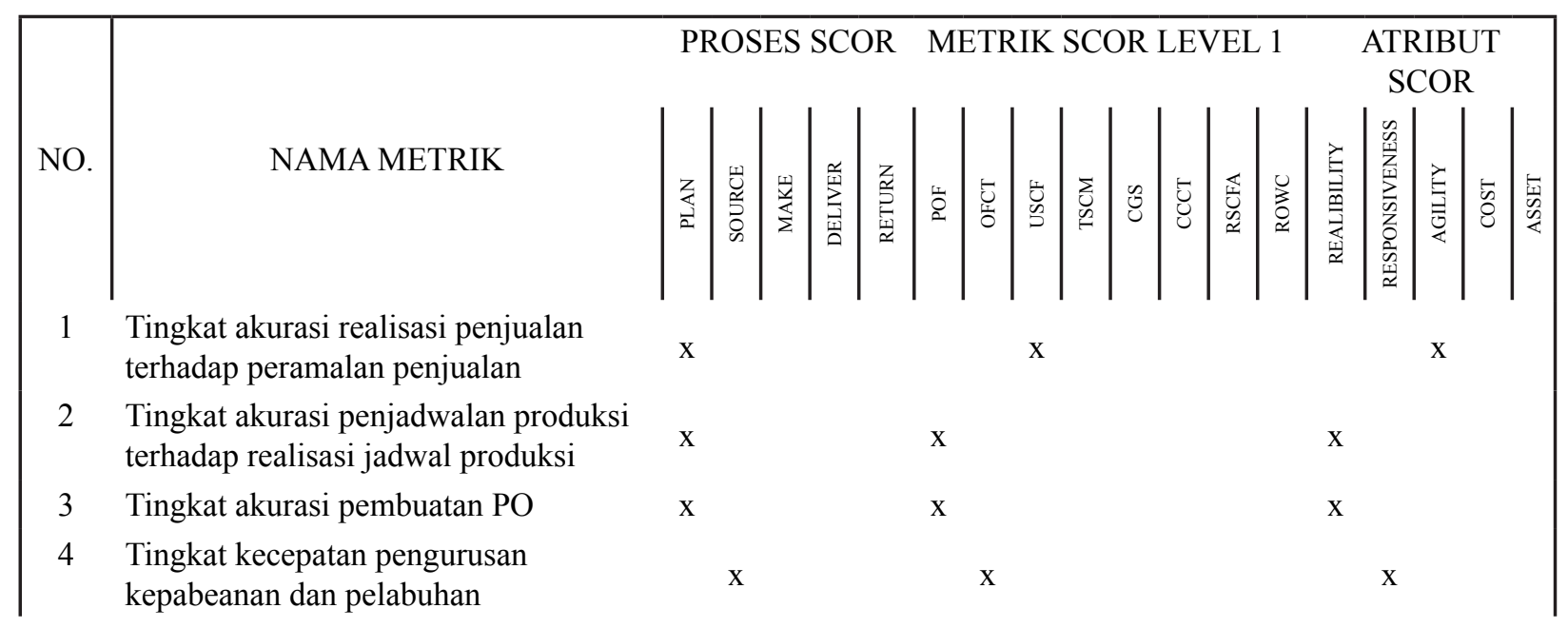


$5 \quad$ Tingkat kecepatan pembongkaran Raw Material impor

6 Tingkat biaya operasional mulai dari pengurusan kepabeanan s/d barang sampai di gudang dibandingkan HPP.

7 Tingkat kecepatan proses klaim kualitas raw material off specs. s/d kesepakatan

8 Tingkat losses hasil Stock Opname x

9 Tingkat downgrade losses of raw material

10 Tingkat jumlah produk yang di recycle

11 Product retention time

12 Tingkat akurasi penjadwalan permintaan release raw material.

13 Tingkat akurasi penjadwalan penerbitan PO WR.

14 Tingkat kecepatan penerbitan release instruction oleh Pendana.

15 Tingkat kecepatan penerbitan konfirmasi order

16 Tingkat kecepatan proses deliveri ke Customer mulai dari Sales Order diterima sampai dengan produk diterima Customer.

17 Tingkat akurasi kuantitas yang dideliveri ke Customer

18 Tingkat akurasi jadwal deliveri ke Customer

19 Days Sales Outstanding

20 Cash To Cash Cycle Time

21 Tingkat kecepatan respon mulai dari komplain diterima dari Customer sampai dengan Sales Order Retur diterima Customer.

22 Tingkat produk retur penjualan.

$$
\mathrm{x}
$$

$\mathrm{x}$

$$
\text { X }
$$

$\mathrm{x}$

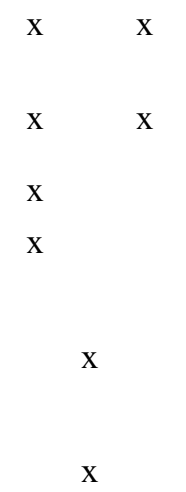

$\mathrm{X}$

$\mathrm{X}$

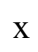

$\mathrm{x}$

5) Tingkat akurasi penjadwalan penerbitan PO WR; 6) Tingkat kecepatan penerbitan konfirmasi order; 7) Tingkat kecepatan proses deliveri ke Customer mulai dari Sales Order diterima sampai dengan produk diterima Customer; 8) Days Sales Outstanding; dan 9) Tingkat produk retur penjualan.

Skor kinerja Periode I selanjutnya dievaluasi dan dilakukan upaya perbaikan dengan cara meningkatkan kerjasama antar pihak yang terlibat dalam rantai pasok dan meningkatkan kecepatan proses kerja. Skor hasil pengukuran metrik Periode II adalah $83,64 \%$ atau meningkat $5,3 \%$ jika 
dibandingkan dengan skor pengukuran Periode I. Dari 22 metrik, terdapat 2 (dua) metrik dengan skor $\leq 60 \%$, yaitu : 1) Tingkat kecepatan pembongkaran Raw Material impor; dan 2) Tingkat kecepatan penerbitan konfirmasi order.

Kinerja proses SCOR tergantung dari kinerja masing-masing metrik aktifitas penyusunnya. Terjadi peningkatan skor kinerja proses SCOR dari 78,00\% (Periode I) menjadi 83,33\% (Periode II) atau meningkat 5,33\%. Untuk skor Atribut SCOR terjadi peningkatan dari $75,42 \%$ (Periode I) menjadi $81.00 \%$ (Periode II) atau meningkat 5,58\%.

\section{SIMPULAN DAN SARAN}

Simpulan yang dapat diambil dari penelitian ini adalah : 1) Rancangan Sistem Pengukuran Kinerja Rantai Pasok PT Sierad Produce Tbk. Unit Feed Mill Sidoarjo adalah terdiri dari : Proses SCOR Level 1 terdiri dari : Plan, Source, Make, Deliver, dan Return; Proses SCOR Level 2 terdiri dari : Plan Supply Chain, Plan Make Plan Source (PLAN); Source Stock Product (SOURCE); Make to Stock (MAKE); Deliver Stock Product (DELIVER); dan Return Devective Product (RETURN); Proses SCOR Level Aktifitas terdiri dari 22 (dua puluh dua) Metrik; 2) Dari hasil pengukuran Periode I dan Periode II, terjadi peningkatan kinerja proses SCOR, dan Atribut SCOR.

Saran-saran terkait dengan hasil penelitian ini adalah : 1) Hasil rancangan sistem pengukuran kinerja rantai pasok digunakan sebagai sarana evaluasi kinerja rantai pasok; 2) Pengukuran kinerja sebaiknya dilakukan secara periodik per bulan agar upaya perbaikan kinerja dilakukan secara konsisten; 3) Hasil rancangan ini sebaiknya dievaluasi setiap tahun untuk mendapatkan metrikmetrik prioritas perbaikan periode berikutnya.

\section{DAFTAR PUSTAKA}

Gasversz, V. 2011. Sistem Manajemen Kinerja Terintegrasi Balance Scorecard dengan Malcolm Baldridge dan Lean Six Sigma Suply Chain Management. Edisi 1, Vinchristo Publication. Bogor.

Helia, VN. 2011. Perancangan dan Pengukuran Kinerja Rantai Pasok di Instalasi Farmasi Rumah Sakit PKU Muhammadiyah. Tesis
Pasca Sarjana, Universitas Islam Indonesia, Yogyakarta.

Huan, Samuel, H., Sheoran, Sunil K. and Wang, G. 2004. A review and analysis of SC operations reference (SCOR) model. International Journal of Supply Chain Management, 9 (1).

Kocaoglu, B., Gulsun, B. and Tanyas, M. 2013. A SCOR based approach for measuring a benchmarkable supply chain performance. Journal of Inteligent Manufacturing, 24 (1): 113-132

Maimaiti, H., Guan, Z. and Wang, B. 2011. Modeling Research on Internal Manufacturing Supply Chain Based on SCOR Model. Selected Papers from the 2011 International Conference on Automation and Robotics (ICAR 2011), Dubai, December 1-2, 2011

Miranda dan Amin, W.T. 2006. Manajemen Logistik dan Supply Chain Management. Harvarindo, Jakarta.

Mutakin, A. 2010. Pengukuran Kinerja Manajemen Rantai Pasokan dengan Pendekatan SCOR Model 9.0 (Studi Kasus di PT Indocement Tunggal Prakarsa Tbk. Skripsi, Departemen Manajemen Fakultas Ekonomi dan Manajemen Institut Pertanian Bogor.

Olsen, EO., Zhou, H., Lee, DMS., Padunchwit, P. 2007. Performance Measurement System and Relationships with Performance Results. International Journal of Productivity and Performance Management, 56 (7) : 559 - 582.

Primantara, A. dan Supriyanto, H. 2010 Pengukuran dan Peningkatan Performansi Supply Chain dengan Pendekatan Model SCOR dan Lean Six Sigma di PT Gunawan Dianjaya Steel, Surabaya. Jurnal Teknik Industri, Institut Sepuluh November Surabaya.

Pujawan, IN. dan Mahendratta. 2010, Supply Chain Management, Edisi Kedua, Guna Widya, Surabaya.

Sheikh, K. 2002. Manufacturing Resource Planning (MRP II ), with Introduction to ERP, SCM, and CRM. McGraw-Hill, New York.

Wibowo. 2011. Manajemen Kinerja. Rajawali Pers, Jakarta.

www.supply-chain.org. Supply Chain Operations 
Reference Model (SCOR). version 7.0; version 8.0 ; version 9.0 ; version 10.0. Washington DC.

Dilihat tanggal 23 Agustus 2012. 